\title{
Natrinema gari sp. nov., a halophilic archaeon isolated from fish sauce in Thailand
}

Correspondence Wonnop Visessanguan wonnop@biotec.or.th

\author{
Wanaporn Tapingkae, ${ }^{1}$ Somboon Tanasupawat, ${ }^{2}$ Takashi Itoh, $^{3}$ \\ Kirk L. Parkin, ${ }^{4}$ Soottawat Benjakul, ${ }^{1}$ Wonnop Visessanguan ${ }^{5}$ \\ and Ruud Valyasevi ${ }^{5}$
}
${ }^{1}$ Department of Food Technology, Faculty of Agro-Industry, Prince of Songkla University, Hat Yai, Songkhla 90112, Thailand
${ }^{2}$ Department of Microbiology, Faculty of Pharmaceutical Sciences, Chulalongkorn University, Bangkok 10330, Thailand
${ }^{3}$ Japan Collection of Microorganisms, RIKEN BioResource Center, 2-1 Hirosawa, Wako-shi, Saitama 351-0198, Japan
${ }^{4}$ Department of Food Science, University of Wisconsin, Madison, WI 53706, USA
${ }^{5}$ National Center for Genetic Engineering and Biotechnology, 113 Thailand Science Park, Paholyothin Rd, Klong 1, Klong Luang, Pathumthani 12120, Thailand

Two Gram-negative, rod-shaped, halophilic archaea, designated strains HIS40-3 ${ }^{\top}$ and HDS3-1, were isolated from anchovy fish sauce (nam-pla) collected from two different locations in Thailand. The two strains were able to grow at $20-60{ }^{\circ} \mathrm{C}$ (optimum $37-40{ }^{\circ} \mathrm{C}$ ), at $1.7-5.1 \mathrm{M} \mathrm{NaCl}$ (optimum 2.6-3.4 M NaCl) and at $\mathrm{pH}$ 5.5-8.5 (optimum $\mathrm{pH}$ 6.0-6.5). Hypotonic treatment with less than $1.7 \mathrm{M} \mathrm{NaCl}$ caused cell lysis. The major polar lipids of the isolates were $\mathrm{C}_{20} \mathrm{C}_{20}$ and $\mathrm{C}_{20} \mathrm{C}_{25}$ derivatives of phosphatidylglycerol, phosphatidylglycerol phosphate methyl ester, phosphatidylglycerol sulfate, two glycolipids and one unidentified lipid. The DNA $\mathrm{G}+\mathrm{C}$ contents were 64.0-65.4 mol\%. In addition to phenotypic and chemotaxonomic characteristics, phylogenetic analysis based on 16S rRNA gene sequence similarities showed that strains HIS40$3^{\top}$ and HDS3-1 were related most closely to species of the genus Natrinema. Levels of $16 S$ rRNA gene sequence similarity between strains HIS40-3 ${ }^{\top}$ and HDS3-1 and the type strains of recognized Natrinema species were 99.1-96.6\%. The two novel strains could be distinguished from recognized Natrinema species on the basis of low levels of DNA-DNA relatedness and differences in whole-cell protein patterns and phenotypic properties. Levels of 16S rRNA gene sequence similarity and DNA-DNA relatedness between the two strains were 99.7 and $77.7 \%$, respectively, suggesting that they should be classified as representing a single species. Based on these taxonomic data, strains HIS40-3 ${ }^{\top}$ and HDS3-1 are considered to represent a novel species of the genus Natrinema, for which the name Natrinema gari sp. nov. is proposed. The type strain is HIS40-3 $3^{\top}\left(=\mathrm{BCC} 24370^{\top}=\mathrm{JCM} 14663^{\top}=\mathrm{PCU} 303^{\top}\right)$.
Fish sauce (nam-pla) is a traditional fermented fish product commonly used as a condiment in South-East Asia. Apart from its unique and pleasant flavour, it provides an important supplementary source of nitrogen

The GenBank/EMBL/DDBJ accession numbers for the $16 \mathrm{~S}$ rRNA gene sequences of strains HIS40-3 ${ }^{\top}$ and HDS3-1 are AB289741 and AB289743, respectively.

Two-dimensional TLC of polar lipids extracted from strains HIS40-3 ${ }^{\top}$ and HDS3-1, maximum-parsimony and maximum-likelihood phylogenetic trees based on 16S rRNA gene sequences and patterns of wholecell proteins are available as supplementary material with the online version of this paper. in the diet of people in this region. Fish sauce contains nitrogen at $20 \mathrm{~g} \mathrm{l}^{-1}$, of which $16 \%$ is present as amino acids (Phithakpol et al., 1995). Fish sauce contains a high concentration of $\mathrm{NaCl}$, allowing various halophilic microorganisms to thrive (Lopetcharat et al., 2001; Tanasupawat \& Komagata, 2001). Nevertheless, just a few types of bacteria have been isolated from fish sauce samples and subjected to taxonomic study. In Thailand, Halobacterium salinarum and Halococcus thailandensis have been isolated from fish sauce samples: these are extremely halophilic archaea that grow optimally at 20-25\% NaCl (Thongthai et al., 1992; Namwong et al., 2007). Other bacteria isolated from fish sauce are moderately halophilic micro-organisms 
that grow optimally at $3-15 \% \mathrm{NaCl}$, such as Tetragenococcus halophilus, Tetragenococcus muriaticus, Halobacillus thailandensis and Lentibacillus juripiscarius (Thongsanit et al., 2002; Chaiyanan et al., 1999; Namwong et al., 2005). At the time of writing, the genus Natrinema comprises five recognized species. Natrinema pellirubrum and Natrinema pallidum were created by McGenity et al. (1998) as a result of reclassification of strains of Halobacterium salinarum and Halobacterium halobium, respectively. On the basis of 16S rRNA gene sequence analysis, phenotypic properties and polar lipid composition, Natrinema versiforme (Xin et al., 2000) and Natrinema altunense (Xu et al., 2005) were also included within the genus. Natrinema ejinorense has been described more recently (Castillo et al., 2006). Here, we describe the taxonomic properties of two extremely halophilic archaea, strains HIS40 $-3^{\mathrm{T}}$ and HDS3-1, isolated from fermented fish sauce, and these are suggested to represent a novel species of the genus Natrinema.

Strains HIS40-3 $3^{\mathrm{T}}$ and HDS3-1 were isolated from anchovy fish sauce fermented for 40 days collected from Samut Prakarn Province and an anchovy fish sauce sample fermented for 3 months collected from Samut Songkram Province, central Thailand, respectively. Samples were plated on agar plates of halophilic medium [per litre: $250 \mathrm{~g} \mathrm{NaCl}, 5 \mathrm{~g}$ Casamino acids, $5 \mathrm{~g}$ yeast extract, $1 \mathrm{~g}$ sodium glutamate, $2 \mathrm{~g} \mathrm{KCl}, 3 \mathrm{~g}$ trisodium citrate, $20 \mathrm{~g} \mathrm{MgSO}_{4} .7 \mathrm{H}_{2} \mathrm{O}, 0.036 \mathrm{~g} \mathrm{FeCl}_{4} .4 \mathrm{H}_{2} \mathrm{O}$, $0.36 \mathrm{mg} \mathrm{MnCl} 2.4 \mathrm{H}_{2} \mathrm{O}, 20 \mathrm{~g}$ agar $\left.(\mathrm{pH} 7.2)\right]$ and incubated at $37{ }^{\circ} \mathrm{C}$ for $1-2$ weeks. A pure culture was obtained by repeated transfers of separate colonies on agar plates of the same medium. Nnm. pallidum JCM $8980^{\mathrm{T}}$, Nnm. pellirubrum JCM $10476^{\mathrm{T}}$ and Nnm. altunense JCM $12890^{\mathrm{T}}$ were used as reference strains in all tests of phenotypic characteristics. Unless otherwise stated, strains were grown in liquid medium (with shaking at 200 r.p.m.) or on agar plates of the halophilic medium and cultivated at $37{ }^{\circ} \mathrm{C}$ for $1-2$ weeks.

Phenotypic characterization was carried out in accordance with the recommended minimal standards for the description of new taxa in the order Halobacteriales (Oren et al., 1997). Colony and cell morphology were examined for cells grown on agar plates at $37{ }^{\circ} \mathrm{C}$ for 14 days. Catalase and oxidase activities and hydrolysis of gelatin, casein, starch and Tween 80 were determined according to the methods of Barrow \& Feltham (1993). Casamino acids were omitted from the test medium for determination of the hydrolysis of gelatin and casein. Utilization of sugars, alcohols, amino acids and organic acids and acid production were determined in modified Leifson medium supplemented with $0.01 \%(\mathrm{w} / \mathrm{v})$ yeast extract and $4.3 \mathrm{M} \mathrm{NaCl}$, but with casitone and Tris/HCl omitted (Leifson, 1963). Growth at various temperatures $\left(20-60{ }^{\circ} \mathrm{C}\right)$ was examined. $\mathrm{NaCl}$ requirement was determined in medium containing various $\mathrm{NaCl}$ concentrations $(0-5.1 \mathrm{M})$. Similarly, the requirement of the strains for $\mathrm{Mg}^{2+}$ was tested in halophilic medium without $\mathrm{MgSO}_{4} \cdot 7 \mathrm{H}_{2} \mathrm{O}$ but supplemented with $0-1.0 \mathrm{M} \mathrm{MgCl}$. Growth was determined by measuring culture turbidity at
$600 \mathrm{~nm}$. Anaerobic growth was tested on agar plates in the presence of nitrate $\left(1 \mathrm{~g} \mathrm{l}^{-1}\right)$, L-arginine $\left(1 \mathrm{~g} \mathrm{l}^{-1}\right)$ or DMSO $\left(10 \mathrm{~g} \mathrm{l}^{-1}\right)$. Production of indole and reduction of nitrate and nitrite were also tested. Determination of the antibiotic susceptibility of the strains was tested according to the methods described by Stan-Lotter et al. (2002). Menaquinones were analysed as described by Komagata \& Suzuki (1987). Polar lipids were determined according to the method of Minnikin et al. (1984).

DNA was isolated and purified according to the method of Saito \& Miura (1963). The G $+\mathrm{C}$ content was determined by the method of Tamaoka \& Komagata (1984) by using reversed-phase HPLC. DNA-DNA hybridization was determined as reported by Ezaki et al. (1989) and levels of relatedness were determined by the colorimetric method as reported by Tanasupawat et al. (2000). The 16S rRNA gene sequences of strains HIS40-3 $3^{\mathrm{T}}$ and HDS3-1, comprising 1405 and $1353 \mathrm{bp}$, respectively, were amplified by PCR with primers D30F (5'-ATTCCGGTTGATCCTGC-3', positions 6-12 according to the Escherichia coli numbering system) and D56R (5'-CTTGTTACGACTT-3', positions 1492-1509). The amplified DNA fragment was separated by agarose gel electrophoresis and was recovered by using a GenElute Minus EtBr Spin Column (Sigma). The sequence was determined by using a BigDye Terminator Cycle Sequencing Ready Reaction kit (v. 3.0; Applied Biosystems) in an ABI PRISM 310 Genetic Analyzer (Applied Biosystems) with the following primers: D30F, D33R (5'TCGCGCCTGCGCCCCGT-3', positions 344-360), D34R (5'-GGTCTCGCTCGTTGCCTG-3', positions 1096-1113) and D56R. The sequence was compared with reference $16 \mathrm{~S}$ rRNA gene sequences available in the GenBank and EMBL databases obtained from the National Center for Biotechnology Information database using BLAST searches. The alignment was subjected to phylogenetic analysis with the neighbour-joining (Saitou \& Nei, 1987), maximumlikelihood and maximum-parsimony methods, by using programs in the CLUSTAL_X and MEGA 4 packages (Thompson et al., 1997; Tamura et al., 2007). Confidence in the branching pattern was assessed by analysis of 1000 bootstrap replicates (Felsenstein, 1985).

Cells of strains HIS40-3 $3^{\mathrm{T}}$ and HDS3-1 were motile, Gramnegative rods $(0.5-0.8 \times 2.0-3.0 \mu \mathrm{m})$ (Fig. 1). Colonies formed on agar plates were circular (1-2 mm in diameter), smooth, translucent and pale-orange pigmented. The two strains were able to grow over a wide range of $\mathrm{NaCl}$ concentrations, from 1.7 M (approximately $10 \%$ ) to $5.1 \mathrm{M}$ (approximately $30 \%$ ). Hypotonic treatment with less than 1.7 M NaCl caused cell lysis. Strains HIS40-3 ${ }^{\mathrm{T}}$ and HDS3-1 grew optimally in the presence of 2.6-3.4 M (15-20\%) $\mathrm{NaCl}$, similar to most halophilic archaea (Grant et al., 2001). The strains grew over a wide range of $\mathrm{MgCl}_{2}$ concentrations from 0 to $1.0 \mathrm{M}$ and grew optimally at around $0.1-0.2 \mathrm{M}$. The two strains grew at $20-60{ }^{\circ} \mathrm{C}$ (optimum $37-40{ }^{\circ} \mathrm{C}$ ) and at $\mathrm{pH} 5.5-8.5$ (optimum $\mathrm{pH}$ 6.0-6.5). The two strains were positive for catalase and oxidase. Indole production from tryptophan was 

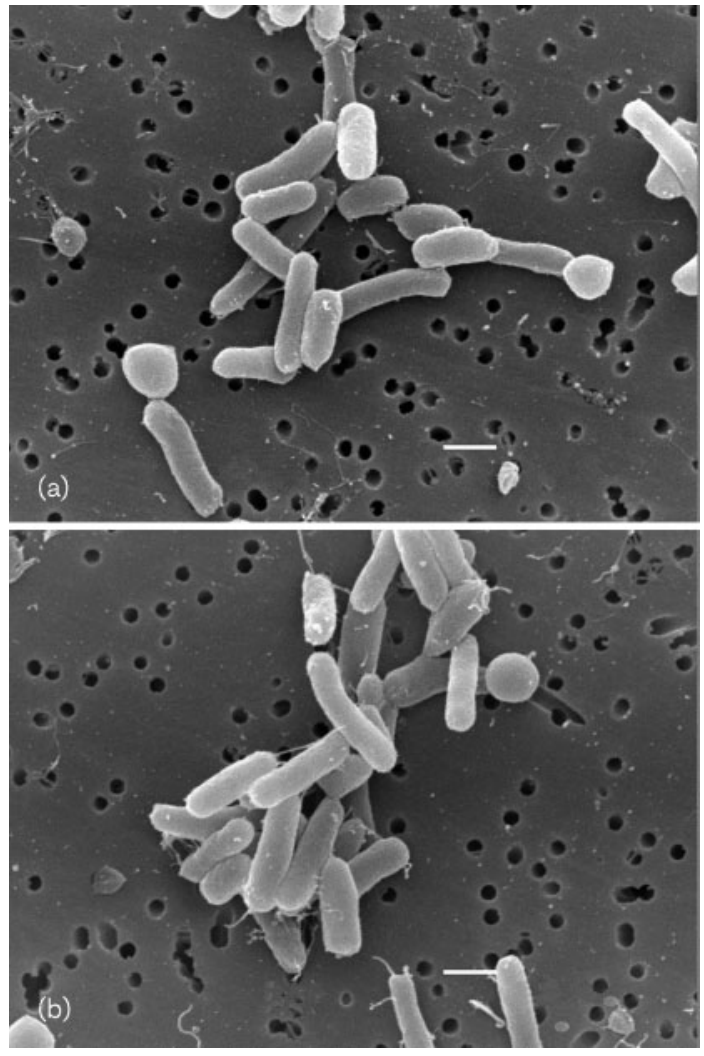

Fig. 1. Scanning electron micrographs of cells of strain $\mathrm{HIS} 40-3^{\top}$ (a) and strain HDS3-1 (b) grown on halophilic medium at $37^{\circ} \mathrm{C}$. Bars, $1 \mu \mathrm{m}$.

negative. Casein, starch and Tween 80 were not hydrolysed. Gelatin was liquefied. The strains showed anaerobic growth in the presence of DMSO but not with nitrate or arginine. Nitrate was not reduced and gas formation was not observed. The strains were sensitive to rifampicin, bacitracin and novobiocin. Strains HIS40-3 ${ }^{\mathrm{T}}$ and HDS3-1 utilized several carbohydrates. Among them, strong acid formation was observed only from glycerol for both strains and from arabinose for strain HIS40-3 $3^{\mathrm{T}}$. There were some differences in the utilization of carbon sources between strains HIS40$3^{\mathrm{T}}$ and HDS3-1. Some characteristics that distinguish strains HIS40-3 $3^{\mathrm{T}}$ and HDS3-1 from other members of the genus Natrinema are summarized in Table 1.

Strains HIS40-3 ${ }^{\mathrm{T}}$ and HDS3-1 possessed two menaquinones, MK-8 (76.3 and 74.6\%, respectively) and MK$8\left(\mathrm{H}_{2}\right)(23.7$ and $25.5 \%)$, which are commonly detected in species of the genus Natrinema (McGenity et al., 1998; Xin et al., 2000). Two-dimensional TLC revealed that the two novel strains possessed glycerol diether analogues of phosphatidylglycerol (PG), phosphatidylglycerol phosphate methyl ester (PGP), phosphatidylglycerol sulfate (PGS), pigment, two glycolipids and one unidentified lipid (see Supplementary Fig. S1, available in IJSEM Online). The core lipids were $\mathrm{C}_{20} \mathrm{C}_{20}$ and $\mathrm{C}_{20} \mathrm{C}_{25}$ diether, as shown from the two PG and PGP spots. The two strains showed two glycolipid spots, tentatively designated GL1 and 2, which might correspond to molecules containing $\mathrm{C}_{20} \mathrm{C}_{20}$ and $\mathrm{C}_{20} \mathrm{C}_{25}$ diether moieties. These two glycolipids were also found in varying amounts in the reference strains Nnm. pallidum JCM $8980^{\mathrm{T}}$, Nnm. pellirubrum JCM $10476^{\mathrm{T}}$ and Nnm. altunense JCM $12890^{\mathrm{T}}$ (McGenity et al., 1998; $\mathrm{Xu}$ et al., 2005). The DNA G + C contents of strains HIS40$3^{\mathrm{T}}$ and HDS3-1 were 65.4 and $64.0 \mathrm{~mol} \%$, respectively.

The neighbour-joining phylogenetic tree constructed on the basis of $16 \mathrm{~S}$ rRNA gene sequence data for the two new isolates and other representative Natrinema species is shown in Fig. 2. Strains HIS40-3 $3^{\mathrm{T}}$ and HDS3-1 formed a distinct cluster that fell within the genus Natrinema. Trees constructed according to the maximum-likelihood and maximum-parsimony methods are shown in Supplementary Fig. S2. 16S rRNA gene sequence similarity between the two novel strains was $99.7 \%$, suggesting that they should be classified as representing a single species or as members of very closely related species. This is in accordance with the morphological and chemotaxonomic similarities detailed above. The nearest neighbours of strains HIS40-3 ${ }^{\mathrm{T}}$ and HDS3-1 were Nnm. pallidum JCM $8980^{\mathrm{T}}$ (99.1 and $99.1 \% 16 \mathrm{~S}$ rRNA gene sequence similarity, respectively), Nnm. pellirubrum JCM $10476^{\mathrm{T}}$ (98.7 and $98.7 \%)$, Nnm. altunense JCM $12890^{\mathrm{T}}$ (98.5 and $98.5 \%$ ), Nnm. versiforme JCM $10478^{\mathrm{T}}$ (98.4 and $98.4 \%$ ) and Nnm. ejinorense JCM $13890^{\mathrm{T}}$ (96.6 and $96.7 \%$ ).

The DNA-DNA hybridization study revealed that strains HIS40- $3^{\mathrm{T}}$ and HDS3-1 were closely related, exhibiting levels of relatedness of $73.5-77.7 \%$ to each other; however, strains HIS40-3 $3^{\mathrm{T}}$ and HDS3-1 showed only low levels of DNA-DNA relatedness to Nnm. pallidum JCM $8980^{\mathrm{T}}$ (40.5 and $42.5 \%$, respectively), Nnm. pellirubrum JCM $10476^{\mathrm{T}}$ (18.7 and $\left.22.0 \%\right)$, Nnm. altunense JCM $12890^{\mathrm{T}}(13.2$ and $16.0 \%)$ and Nnm. versiforme JCM $10478^{\mathrm{T}}$ (19.5 and $\left.18.2 \%\right)$, indicating that these two novel strains are not members of any of these Natrinema species. Each of the values was obtained from two independent determinations. Moreover, the protein pattern of the novel strains was markedly different from those of the Natrinema species representatives analysed herein (Supplementary Fig. S3).

In conclusion, on the basis of growth requirements, poor utilization of carbohydrates, antibiotic susceptibility, menaquinone content, overall phospholipid composition, DNA G $+\mathrm{C}$ contents and 16S rRNA gene sequence analysis, strains HIS40-3 ${ }^{\mathrm{T}}$ and HDS3-1 are considered to represent a single species of the genus Natrinema. However, they could be differentiated from recognized Natrinema species based on levels of DNA-DNA relatedness and differences in whole-cell protein patterns. The results of the present study thus suggest that strains HIS40- $3^{T}$ and HDS3-1 represent a novel species of the genus Natrinema, for which the name Natrinema gari sp. nov. is proposed. 
Table 1. Differential characteristics between strains HIS40-3 ${ }^{\top}$ and HDS3-1 and recognized Natrinema species

Strains: 1, strain HIS40-3 ${ }^{\mathrm{T}} ; 2$, strain HDS3-1; 3, Nnm. pallidum JCM $8980^{\mathrm{T}} ; 4$, Nnm. pellirubrum JCM $10476^{\mathrm{T}} ; 5$, Nnm. altunense JCM $12890^{\mathrm{T}}$ (data in columns 1-5 from this study unless indicated); 6, Nnm. versiforme JCM $10478^{\mathrm{T}}$ (data from Xin et al., 2000); 7, Nnm. ejinorense JCM 13890 ${ }^{\mathrm{T}}$ (Castillo et al., 2006). +, Positive; -, negative; +/-, doubtful; ND, no data available.

\begin{tabular}{|c|c|c|c|c|c|c|c|}
\hline Characteristic & 1 & 2 & 3 & 4 & 5 & 6 & 7 \\
\hline Cell morphology & Rods & Rods & Rods & Rods & Rods & Pleomorphic & Pleomorphic \\
\hline Motility & + & + & + & + & + & - & - \\
\hline $\begin{array}{l}\mathrm{NaCl} \text { concentration }(\mathrm{M}) \text { required } \\
\text { to prevent cell lysis }\end{array}$ & $>1.7$ & $>1.7$ & $>1.7$ & $>1.7$ & $>2.1$ & $>1.0$ & $>1.5$ \\
\hline $\mathrm{NaCl}$ requirement $(\mathrm{M})$ & $\geqslant 1.7$ & $\geqslant 1.7$ & $\geqslant 1.7$ & $\geqslant 1.7$ & $\geqslant 2.1$ & $\geqslant 1.5$ & $\geqslant 1.8$ \\
\hline $\mathrm{MgCl}_{2}$ optimum $(\mathrm{M})$ & $0.1-0.2$ & $0.1-0.2$ & $0.1-0.2$ & $0.1-0.2$ & $0.1-0.2$ & 0.15 & ND \\
\hline \multicolumn{8}{|l|}{ Temperature for growth $\left({ }^{\circ} \mathrm{C}\right)$} \\
\hline Range & $20-60$ & $20-60$ & $25-60$ & $20-60$ & $20-60$ & $20-53$ & $25-50$ \\
\hline Optimum & $37-40$ & $37-40$ & $30-37$ & $30-37$ & $37-40$ & $37-46$ & 37 \\
\hline \multicolumn{8}{|l|}{$\mathrm{pH}$ for growth } \\
\hline Range & $5.5-8.5$ & $5.5-8.5$ & $5.5-8.5$ & $5.5-8.5$ & $6.0-8.5$ & $6.0-8.0$ & $6.0-8.5$ \\
\hline Gas formation from nitrate & - & - & - & - & - & + & + \\
\hline Oxidase activity & + & + & + & - & - & + & + \\
\hline Indole formation & - & - & - & - & - & + & - \\
\hline \multicolumn{8}{|l|}{ Hydrolysis of: } \\
\hline Gelatin & + & + & + & - & + & - & + \\
\hline Starch & - & - & - & - & - & $+1-$ & + \\
\hline Tween 80 & - & - & + & - & + & + & + \\
\hline DNA G $+C$ content $(\mathrm{mol} \%)$ & 65.4 & 64.0 & 63.9 & 62.9 & $65.6^{\star}$ & 64.2 & 64.7 \\
\hline
\end{tabular}

${ }^{\star}$ Data from Xu et al. (2005).

\section{Description of Natrinema gari sp. nov.}

Natrinema gari (ga'ri. L. gen. n. gari of a fish sauce, pertaining to the isolation of strains from fermented fish sauce).
Cells are motile, Gram-negative rods, 0.5-0.8 $\times 2.0-3.0 \mu \mathrm{m}$ in size. Colonies are pale orange, smooth, circular and elevated. Growth is chemo-organotrophic. Requires at least $1.7 \mathrm{M} \mathrm{NaCl}$ for growth (optimum 2.6-3.4 M $\mathrm{NaCl}$ ).

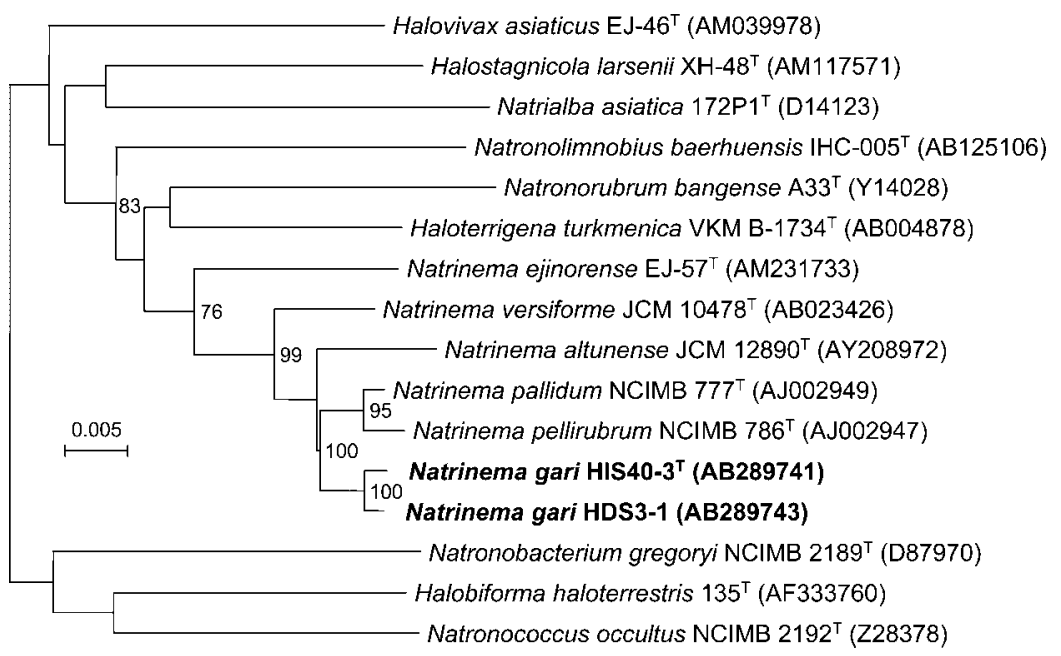

Fig. 2. Phylogenetic tree showing the relationships between strains HIS40-3 ${ }^{\top}$, HDS3-1 and related archaeal species based on $16 \mathrm{~S}$ rRNA gene sequences. The branching pattern was generated according to the neighbour-joining method. Bootstrap values above $70 \%$, based on 1000 replications, are shown at nodes. Bar, 0.5 substitutions per 100 nucleotide positions. 
Growth occurs at $0-1.0 \mathrm{M} \mathrm{MgCl}_{2}$ (optimum 0.1-0.2 M $\mathrm{MgCl}_{2}$ ). The $\mathrm{pH}$ range for growth is 5.5-8.5 (optimum $\mathrm{pH}$ 6.0-6.5). The temperature range for growth is 20$60{ }^{\circ} \mathrm{C}$ (optimum $37-40{ }^{\circ} \mathrm{C}$ ). Grows anaerobically in the presence of DMSO but not nitrate. Catalase- and oxidasepositive. Nitrate and nitrite are not reduced. Negative for production of indole. Casein, starch and Tween 80 are not hydrolysed. Gelatin is hydrolysed. L-Arabinose, D-glucose and glycerol are utilized for growth. Does not utilize inulin, lactose, maltose, D-mannitol, D-mannose, melibiose, rhamnose, D-ribose, sorbitol, sucrose, D-xylose or citrate. Acid is produced from L-arabinose and glycerol. Susceptible to bacitracin $(10 \mathrm{U})$, novobiocin $(5 \mu \mathrm{g})$ and rifampicin $(30 \mu \mathrm{g})$, but resistant to ampicillin $(10 \mu \mathrm{g})$, chloramphenicol $(30 \mu \mathrm{g})$, gentamicin $(10 \mu \mathrm{g})$, kanamycin $(30 \mu \mathrm{g})$, nalidixic acid $(30 \mu \mathrm{g})$, neomycin $(30 \mu \mathrm{g})$, streptomycin $(10 \mu \mathrm{g})$ and tetracycline $(30 \mu \mathrm{g})$. The predominant menaquinone is MK-8. Cells contain $\mathrm{C}_{20} \mathrm{C}_{20}$ and $\mathrm{C}_{20} \mathrm{C}_{25}$ derivatives of phosphatidylglycerol, phosphatidylglycerol phosphate methyl ester, phosphatidylglycerol sulfate, two glycolipids and one unidentified lipid. The DNA G + C content of the type strain is $65.4 \mathrm{~mol} \%$.

The type strain, HIS40-3 $3^{\mathrm{T}}\left(=\mathrm{BCC} 24370^{\mathrm{T}}=\mathrm{JCM} 14663^{\mathrm{T}}\right.$ $=$ PCU $303^{\mathrm{T}}$ ), was isolated from fermented fish sauce in Thailand.

\section{Acknowledgements}

We would like to thank the Thailand Research Fund for financial support under the TRF Senior Research Scholar programme to S. B., the Royal Golden Jubilee PhD programme (grant no. PHD/0119/2548) and Prince of Songkla University for an operating grant under the graduate study programme to $\mathrm{W}$. T. Thanks are also due to the National Center for Genetic Engineering and Biotechnology (BIOTEC) for providing laboratory equipment and experimental space.

\section{References}

Barrow, G. I. \& Feltham, R. K. A. (1993). Cowan and Steel's Manual for the Identification of Medical Bacteria, 3rd edn. Cambridge: Cambridge University Press.

Castillo, A. M., Gutiérrez, M. C., Kamekura, M., Xue, Y., Ma, Y., Cowan, D. A., Jones, B. E., Grant, W. D. \& Ventosa, A. (2006). Natrinema ejinorense sp. nov., isolated from a saline lake in Inner Mongolia, China. Int J Syst Evol Microbiol 56, 2683-2687.

Chaiyanan, S., Chaiyanan, S., Maugel, T., Huq, A., Robb, F. T. \& Colwell, R. R. (1999). Polyphasic taxonomy of a novel Halobacillus, Halobacillus thailandensis sp. nov. isolated from fish sauce. Syst Appl Microbiol 22, 360-365.

Ezaki, T., Hashimoto, Y. \& Yabuuchi, E. (1989). Fluorometric deoxyribonucleic acid-deoxyribonucleic acid hybridization in microdilution wells as an alternative to membrane filter hybridization in which radioisotopes are used to determine genetic relatedness among bacterial strains. Int J Syst Bacteriol 39, 224-229.

Felsenstein, J. (1985). Confidence limits on phylogenies: an approach using the bootstrap. Evolution 39, 783-791.

Grant, W. D., Kamekura, M., McGenity, T. J. \& Ventosa, A. (2001). Order I. Halobacteriales Grant and Larsen 1989b, 495 VP (Effective publication: Grant and Larsen 1989a, 2216). In Bergey's Manual of
Systematic Bacteriology, 2nd edn, vol. 1, pp. 294-334. Edited by D. R. Boone, R. W. Castenholz \& G. M. Garrity. New York: Springer.

Komagata, K. \& Suzuki, K. (1987). Lipid and cell-wall analysis in bacterial systematics. Methods Microbiol 19, 161-207.

Leifson, E. (1963). Determination of carbohydrate metabolism of marine bacteria. J Bacteriol 85, 1183-1184.

Lopetcharat, K., Choi, Y. J., Park, J. W. \& Daeschel, M. A. (2001). Fish sauce products and manufacturing: a review. Food Rev Int 17, 68-88.

McGenity, T. J., Gemmell, R. T. \& William, D. G. (1998). Proposal of a new halobacterial genus Natrinema gen. nov., with two species Natrinema pellirubrum nom. nov. and Natrinema pallidum nom. nov. Int J Syst Bacteriol 48, 1187-1196.

Minnikin, D. E., O'Donnell, A. G., Goodfellow, M., Alderson, G., Athalye, M., Schaal, A. \& Parlett, J. H. (1984). An integrated procedure for the extraction of bacterial isoprenoid quinones and polar lipids. J Microbiol Methods 2, 233-241.

Namwong, S., Tanasupawat, S., Smitinont, T., Visessanguan, W., Kudo, T. \& Itoh, T. (2005). Characterization of Lentibacillus salicampi and Lentibacillus juripiscarius sp. nov. isolated from fish sauce in Thailand. Int J Syst Evol Microbiol 55, 315-320.

Namwong, S., Tanasupawat, S., Visessanguan, W., Kudo, T. \& Itoh, T. (2007). Halococcus thailandensis sp. nov., from fish sauce in Thailand. Int J Syst Evol Microbiol 57, 2199-2203.

Oren, A., Ventosa, A. \& Grant, W. D. (1997). Proposed minimal standards for description of new taxa in the order Halobacteriales. Int J Syst Bacteriol 47, 233-238.

Phithakpol, B., Varanyanond, W., Reungmaneepaitoon, S. \& Wood, H. (1995). The Traditional Fermented Foods of Thailand. Kuala Lumpur: ASEAN Food Handling Bureau Level 3.

Saito, H. \& Miura, K. I. (1963). Preparation of transforming deoxyribonucleic acid by phenol treatment. Biochim Biophys Acta 72, 619-629.

Saitou, N. \& Nei, M. (1987). The neighbor-joining method: a new method for reconstructing phylogenetic trees. Mol Biol Evol 4, 406425.

Stan-Lotter, H., Pfaffenhuemer, M., Legat, A., Busse, H.-J., Radax, C. \& Gruber, C. (2002). Halococcus dombrowskii sp. nov., an archaeal isolate from a Permian alpine salt deposit. Int J Syst Evol Microbiol 52, 1807-1814.

Tamaoka, J. \& Komagata, K. (1984). Determination of DNA base composition by reversed-phase high-performance liquid chromatography. FEMS Microbiol Lett 25, 125-128.

Tamura, K., Dudley, J., Nei, M. \& Kumar, S. (2007). MEGA4: molecular evolutionary genetics analysis (MEGA) software version 4.0. Mol Biol Evol 24, 1596-1599.

Tanasupawat, S. \& Komagata, K. (2001). Lactic acid bacteria in fermented foods in Southeast Asia. In Microbial Diversity in Asia. Technology and Prospects, pp. 43-59. Edited by B. H. Nga, H. M. Tan \& K. Suzuki. Singapore: World Scientific Publishing.

Tanasupawat, S., Shida, O., Okada, S. \& Komagata, K. (2000). Lactobacillus acidipiscis sp. nov., and Weissella thailandensis sp. nov., isolated from fermented fish in Thailand. Int J Syst Evol Microbiol 50, 1479-1485.

Thompson, J. D., Gibson, T. J., Plewniak, F., Jeanmougin, F. \& Higgins, D. G. (1997). The CLUSTAL_X windows interface: flexible strategies for multiple sequence alignment aided by quality analysis tools. Nucleic Acids Res 25, 4876-4882.

Thongsanit, J., Tanasupawat, S., Keeratipibul, S. \& Jatikavanich, S. (2002). Characterization and identification of Tetragenococcus halophilus and Tetragenococcus muriaticus strains from fish sauce (nampla). Jpn J Lactic Acid Bacteria 13, 46-52. 
Thongthai, C., McGenity, T. J., Suntinanalert, P. \& Grant, W. D. (1992). Isolation and characterization of an extremely halophilic archaeobacterium from traditional fermented Thai fish sauce (nampla). Lett Appl Microbiol 14, 111-114.

Xin, H., Itoh, T., Zhou, P.-J., Suzuki, K., Kamekura, M. \& Nakase, T. (2000). Natrinema versiforme sp. nov., an extremely halophilic archaeon from Aibi salt lake, Xinjiang, China. Int $J$ Syst Evol Microbiol 50, 1297-1303.

Xu, X.-W., Ren, P.-G., Liu, S.-J., Wu, M. \& Zhou, P.-J. (2005). Natrinema altunense sp. nov., an extremely halophilic archaeon isolated from a salt lake in Altun Mountain in Xinjiang, China. Int $J$ Syst Evol Microbiol 55, 1311-1314. 